\title{
Use of High-Throughput Sequencing and Two RNA Input Methods to Identify Viruses Infecting Tomato Crops
}

\author{
Ayoub Maachi ${ }^{1}\left(\mathbb{D}\right.$, Covadonga Torre $^{1}\left(\mathbb{D}\right.$, Raquel N. Sempere $^{1}$, Yolanda Hernando ${ }^{1}$, Miguel A. Aranda ${ }^{2}(\mathbb{D}$ \\ and Livia Donaire $2, *$ (D) \\ 1 Abiopep S.L., Parque Científico de Murcia, 30100 Murcia, Spain; a.maachi@abiopep.com (A.M.); \\ ctorre@abiopep.com (C.T.); rnsempere@abiopep.com (R.N.S.); yh.saiz@abiopep.com (Y.H.) \\ 2 Department of Stress Biology and Plant Pathology, Centro de Edafología y Biología Aplicada del \\ Segura (CEBAS)-CSIC, 30100 Murcia, Spain; m.aranda@cebas.csic.es \\ * Correspondence: ldonaire@cebas.csic.es
}

check for updates

Citation: Maachi, A.; Torre, C.; Sempere, R.N.; Hernando, Y.; Aranda, M.A.; Donaire, L. Use of

High-Throughput Sequencing and Two RNA Input Methods to Identify Viruses Infecting Tomato Crops. Microorganisms 2021, 9, 1043. https:// doi.org/10.3390/microorganisms 9051043

Academic Editor: Elvira Fiallo-Olivé

Received: 22 April 2021

Accepted: 10 May 2021

Published: 12 May 2021

Publisher's Note: MDPI stays neutral with regard to jurisdictional claims in published maps and institutional affiliations.

Copyright: (c) 2021 by the authors. Licensee MDPI, Basel, Switzerland. This article is an open access article distributed under the terms and conditions of the Creative Commons Attribution (CC BY) license (https:// creativecommons.org/licenses/by/ $4.0 /)$.

\begin{abstract}
We used high-throughput sequencing to identify viruses on tomato samples showing virus-like symptoms. Samples were collected from crops in the Iberian Peninsula. Either total RNA or double-stranded RNA (dsRNA) were used as starting material to build the cDNA libraries. In total, seven virus species were identified, with pepino mosaic virus being the most abundant one. The dsRNA input provided better coverage and read depth but missed one virus species compared with the total RNA input. By performing in silico analyses, we determined a minimum sequencing depth per sample of 0.2 and 1.5 million reads for dsRNA and rRNA-depleted total RNA inputs, respectively, to detect even the less abundant viruses. Primers and TaqMan probes targeting conserved regions in the viral genomes were designed and/or used for virus detection; all viruses were detected by qRT-PCR/RT-PCR in individual samples, with all except one sample showing mixed infections. Three virus species (Olive latent virus 1, Lettuce ring necrosis virus and Tomato fruit blotch virus) are herein reported for the first time in tomato crops in Spain.
\end{abstract}

Keywords: high-throughput sequencing (HTS); tomato; virus; dsRNA; total RNA; OLV1; LRNV; ToFBV

\section{Introduction}

Tomato (Solanum Lycopersicum L.) is one of the most important vegetable crops. The worldwide production of tomato in 2019 was more than 182 million tons (FAOSTAT, 2019; http:/ / www.fao.org/faostat/; accessed on September 2020). Spain is one of the world's leading producers of tomato plants for fresh consumption, second in the European Union after Italy (Eurostat 2019; https:/ / ec.europa.eu/eurostat/371; accessed on September 2020). Tomato cultivation in Spain is very intensive, with significant acreage devoted to greenhouse production. The major threats to tomato intensive cultivation are viral diseases, which are responsible for significant yield and fruit quality losses, causing important economic damage [1]. The main viruses frequently reported to affect tomato crops include tomato yellow leaf curl virus (TYLCV), pepino mosaic virus (PepMV), tomato spotted wilt virus (TSWV) and tomato chlorosis virus (ToCV), with all four of them having been reported in the Iberian Peninsula (EPPO). Nevertheless, emerging viruses, i.e., those recently reported and the incidence or geographic range of which increase rapidly [2], often cause the most important problems. A recent example of an emerging virus infecting tomato crops in the Iberian Peninsula is tomato brown rugose fruit virus (ToBRFV) (EPPO). The availability of sensitive and reliable virus discovery and detection techniques is crucial for diagnosing and controlling viral diseases, as well as anticipating problems that are potentially caused by major, emerging, or new viruses.

High-throughput sequencing (HTS) technologies enable, in a relatively short period of time, the characterization of plant viromes, allowing both the detection of known viruses 
and the discovery of novel ones [3]. These technologies have been successfully used with several crop species, including tomato plants [4-9]. The application of HTS to samples from tomato crops in China revealed the presence of 22 viruses, of which five of them had not been reported previously to infect plants of this species [8]. Another study, comparing the diversity of viral populations between tomato plants and neighboring Solanum nigrum plants using HTS, showed a large variability in virome richness, but with little overlapping of the viruses found in both species [9]. In addition to its detection potential, different works have shown that HTS can increase the resolution of virus population genetics and evolution studies and also allows the determination of the complete or near-complete genomes of novel viruses without any prior knowledge $[3,10]$. To date, different starting materials have been used for metagenomic studies, including double-stranded RNA (dsRNA), total RNA depleted of ribosomal RNA (rRNA-depleted total RNA), virion associated nucleic acids (VANA) and small RNAs (sRNAs). The comparison between methods using different starting materials has shown differences in the spectrum of viruses or viroids that can be detected. Previous works have shown that the outcome of rRNA-depleted total RNA-based methods tends to be virus-dependent; sRNA sequencing is better than rRNA-depleted total RNA for the detection of viroids $[10,11]$ and both dsRNA and VANA allowed for the enrichment of virus sequences in the samples [12].

Here, we used the rRNA-depleted total RNA and dsRNA approaches to identify the viruses present in tomato samples from plants exhibiting virus-like symptoms. We compared the virus diversity and mapping reads between two replicates from total RNA extractions. In addition, we adopted an in silico approach to determine the minimum sequencing depth needed to detect the less abundant viruses in our sample pools. We identified seven known virus species, three of which are reported for the first time in tomato plants in Spain: Lettuce ring necrosis virus, Olive latent virus 1, and Tomato fruit blotch virus.

\section{Materials and Methods}

\subsection{Plant Material}

Twenty samples of tomato leaves exhibiting symptoms suggesting viral infection were collected during the 2015-2020 period from different locations in Spain and Portugal (Table 1). A portion of leaf tissue from each sample was placed in 1.5-mL tubes, frozen in liquid nitrogen, and stored at $-80^{\circ} \mathrm{C}$ until RNA extraction. 
Table 1. Description of samples and confirmation of viral infections by means of qRT-PCR or conventional RT-PCR.

\begin{tabular}{|c|c|c|c|c|c|c|c|c|c|c|c|}
\hline \multirow{2}{*}{ Sample ID } & \multirow{2}{*}{ Surveyed } & \multirow{2}{*}{ Location } & \multirow{2}{*}{ Symptoms } & \multicolumn{8}{|c|}{ Virus Detected ${ }^{1}$} \\
\hline & & & & OLV1 & TYLCV & ToCV & STV $^{2}$ & ToFBV & PepMV-EU & PepMV-CH2 & LRNV \\
\hline R20-01 & March 2020 & Almería & Vein clearing & - & - & - & + & - & ++ & +++ & +++ \\
\hline R19-12 & November 2019 & Almería & Necrotic spots on leaves & - & - & + & + & - & + & +++ & + \\
\hline R19-09 & October 2019 & Almería & Leaf curling, leaf mosaics & - & - & - & + & - & +++ & +++ & - \\
\hline R19-08 & October 2019 & Almería & Leaf curling, leaf mosaics & - & - & - & - & - & +++ & ++ & - \\
\hline R19-07 & September 2019 & Almería & $\begin{array}{l}\text { Chlorosis, yellow spots on } \\
\text { leaves, leaf mosaics }\end{array}$ & - & - & - & + & ++ & +++ & ++ & - \\
\hline R17-01 & Febuary 2017 & Murcia & $\begin{array}{l}\text { Upward curling of leaves, } \\
\text { chlorosis on leaves }\end{array}$ & - & - & - & - & ++ & + & ++ & - \\
\hline $\mathrm{H}-57$ & December 2016 & Murcia & Leaf mosaics & - & - & - & + & - & ++ & ++ & - \\
\hline $\mathrm{H}-55$ & June 2016 & Murcia & Leaf distortion & - & - & + & + & - & - & ++ & - \\
\hline $\mathrm{H}-54$ & May 2016 & Murcia & Leaf distortion & - & - & - & + & - & ++ & ++ & - \\
\hline $\mathrm{H}-53$ & May 2016 & Murcia & Leaf distortion & - & + & + & + & +++ & + & +++ & - \\
\hline H-52 & May 2016 & Murcia & Distortion and mosaic in fruit & - & + & + & + & +++ & - & +++ & - \\
\hline $\mathrm{H}-50$ & April 2016 & Murcia & Leaf distortion & - & - & - & + & - & + & +++ & - \\
\hline $\mathrm{H}-43$ & December 2015 & Granada & No clear symptoms & - & - & - & + & - & - & + & - \\
\hline $\mathrm{H}-42$ & December 2015 & Granada & Leaf curling & - & ++ & - & - & - & + & + & - \\
\hline H-31 & October 2015 & Almería & Yellow mosaic & - & ++ & + & + & - & - & - & - \\
\hline $\mathrm{H}-13$ & Aprli 2015 & Portugal $^{3}$ & No clear symptoms & - & + & - & - & - & - & +++ & - \\
\hline $\mathrm{H}-11$ & April 2015 & Portugal $^{3}$ & No clear symptoms & ++ & - & - & + & - & - & ++ & - \\
\hline $\mathrm{H}-10$ & April 2015 & Almería & $\begin{array}{l}\text { Necrosis, yellow mosaic and } \\
\text { distortion of leaves }\end{array}$ & - & + & ++ & + & - & + & ++ & + \\
\hline H-09 & April 2015 & Almería & $\begin{array}{l}\text { Necrosis, yellow mosaic and } \\
\text { distortion of leaves }\end{array}$ & + & + & ++ & + & - & + & +++ & + \\
\hline
\end{tabular}

${ }^{1}$ Relative amount of viral RNA denoted as follows: $+++14<\mathrm{Ct}<18 ;++18<\mathrm{Ct}<28 ;+\mathrm{Ct}>28$; Ct: cycle threshold; ${ }^{2}$ conventional RT-PCR; ${ }^{3}$ Torres Vedras (Lisbon). 


\subsection{Nucleic Acid Extraction, Library Construction and Sequencing}

For the total RNA extraction, $100 \mathrm{mg}$ of leaf tissue from each individual sample was ground until attaining a fine powder with a mortar and pestle in the presence of liquid nitrogen. Total RNA was extracted using TRI Reagent (Sigma-Aldrich, St. Louis, MO, USA) following the manufacturer's protocol. For the dsRNA extraction, $100 \mathrm{mg}$ of leaf tissue from each sample was pooled and ground. dsRNA was purified using the protocol from Valverde et al. [13] with Whatman CF-11 cellulose powder (GE Healthcare Life Science Corp., Piscataway, NJ, USA). Both preparations were subjected to RNase-free DNase I treatment (New England Biolabs, Ipswich, MA, USA), following the manufacturer's protocol, to remove traces of DNA, and the dsRNA preparation was also treated with RNase A (Machery-Nagel, Duren, Germany), following the protocol described in [14], to remove single-stranded RNA traces. After these treatments, the preparations were cleaned up by phenol/chloroform extraction [14] and their integrity was confirmed using gel electrophoresis. The quantity of the total RNA was assessed using a Nanodrop ${ }^{\mathrm{TM}}$ One Microvolume UV-Vis Spectrophotometer (Thermo Fisher Scientific, Waltham, MA, USA) and a Qubit ${ }^{\mathrm{TM}}$ 3.0 Fluorometer (Thermo Fisher Scientific), and individual samples were normalized to a final concentration of $20 \mathrm{ng} / \mu \mathrm{L}$. Two identical pools denoted Tom 1 and Tom 2 were prepared by adding $7.5 \mu \mathrm{L}$ from each total RNA sample to obtain a final amount of $3 \mu \mathrm{g}$ of total RNA in $150 \mu \mathrm{L}$ of sterile MiliQ water. The dsRNA sample (denoted as TomDS) had a final volume of $50 \mu \mathrm{L}$ in sterile MiliQ water. The samples were sent to Macrogen (Seoul, Korea) for library preparation and sequencing. The quality and quantity of the RNA in the three samples were further analyzed using a 2100 Bioanalyzer (Agilent Technologies, Palo Alto, CA, USA). For the three samples, cDNA libraries were synthesized using a TrueSeq Stranded Total RNA sample preparation kit (Illumina, San Diego, CA, USA) with ribosomal depletion using a Ribo-Zero plant kit (Illumina). Sequencing was performed with the Illumina NovaSeq 6000 platform to obtain $150 \mathrm{bp}$ paired-end reads.

\subsection{Bioinformatic Analysis}

Raw reads were analyzed using the custom bioinformatic pipeline implemented in the R language, as described in Figure 1. Paired-end reads in fastq format served as the input. The quality of the raw reads was screened using the FastQC program (http: / /www.bioinformatics.babraham.ac.uk/projects/fastqc; accessed on May 2020). Adapters and low-quality reads $(\mathrm{Phred}<30$ ) were trimmed from each data set using Trimmomatic v0.39 [15]. After this step, paired-end reads were repaired using BBMap [16]. Host reads were filtered out by aligning reads to the host genome (Tomato genome version SL2.4) using Bowtie2 [17]. Unmapped reads were subjected to de novo assembly using Trinity v2.10 [18]. For virus detection, contigs were aligned against a custom plant virus nucleotide database using BLASTn [19]. To build the virus database, viral sequences fitting the criteria of host: Viridiplantae and sequence length: 800-23,000 nt were downloaded from NCBI Virus (https:/ / www.ncbi.nlm.nih.gov/labs/virus/vssi/\#/; accessed on May 2020). The database was built using makeblastdb, and low-complexity sequences were filtered out with dustmasker [20]. Sequences sharing $98 \%$ at both nucleotide (nt) and amino acid (aa) levels were collapsed using cd-hit [21]. After BLASTn, viral hits were filtered using the following criteria: contig length between 0.5 to $14 \mathrm{~kb}$, e-value lower than $10^{-4}$, and length of alignment between the query and the hit $\geq 300$ nt. Pyfasta v0.5.2 (https: //pypi.org/project/pyfasta/; accessed on May 2020) was used to retrieve the sequences of the reference viruses detected. Only one random accession for each virus was retrieved in the case that more than one accession for the same virus was found by BLASTn. These viral sequences were used as the reference to re-map the filtered reads using BWA with the mem algorithm [22]. From these alignments, virus genome coverage and average depth were calculated using SAMtools [23] and our own R script. To compare the percentage of identity of a given virus across the three datasets, a consensus sequence was generated 
using SAMtools and the Seqtk tool [24]. In cases where we could not obtain good consensus sequences, the longest contigs were used for these comparisons (Table S1). To determine the closest viral isolate, the consensus or the contig sequences of each virus were screened against its taxon using the NCBI database with BLASTn. The presence of divergent viral sequences was investigated by mapping contigs against a custom plant virus protein database using BLASTx [19], using the same filters as mentioned above. Although we did not find any novel viruses in this work, our pipeline included a step to analyze potential new viral species: ORF Finder (https:/ / www.ncbi.nlm.nih.gov/orffinder/; accessed on May 2020) to predict ORFs of new putative viruses, and BLASTx against non-redundant proteins NCBI database to find the closest virus species. Subsets of reads used to determine the minimum number of reads needed to detect the viruses present in the datasets were obtained with Seqtk [24], using different seed values (100 and 120) in case two replicates were generated.

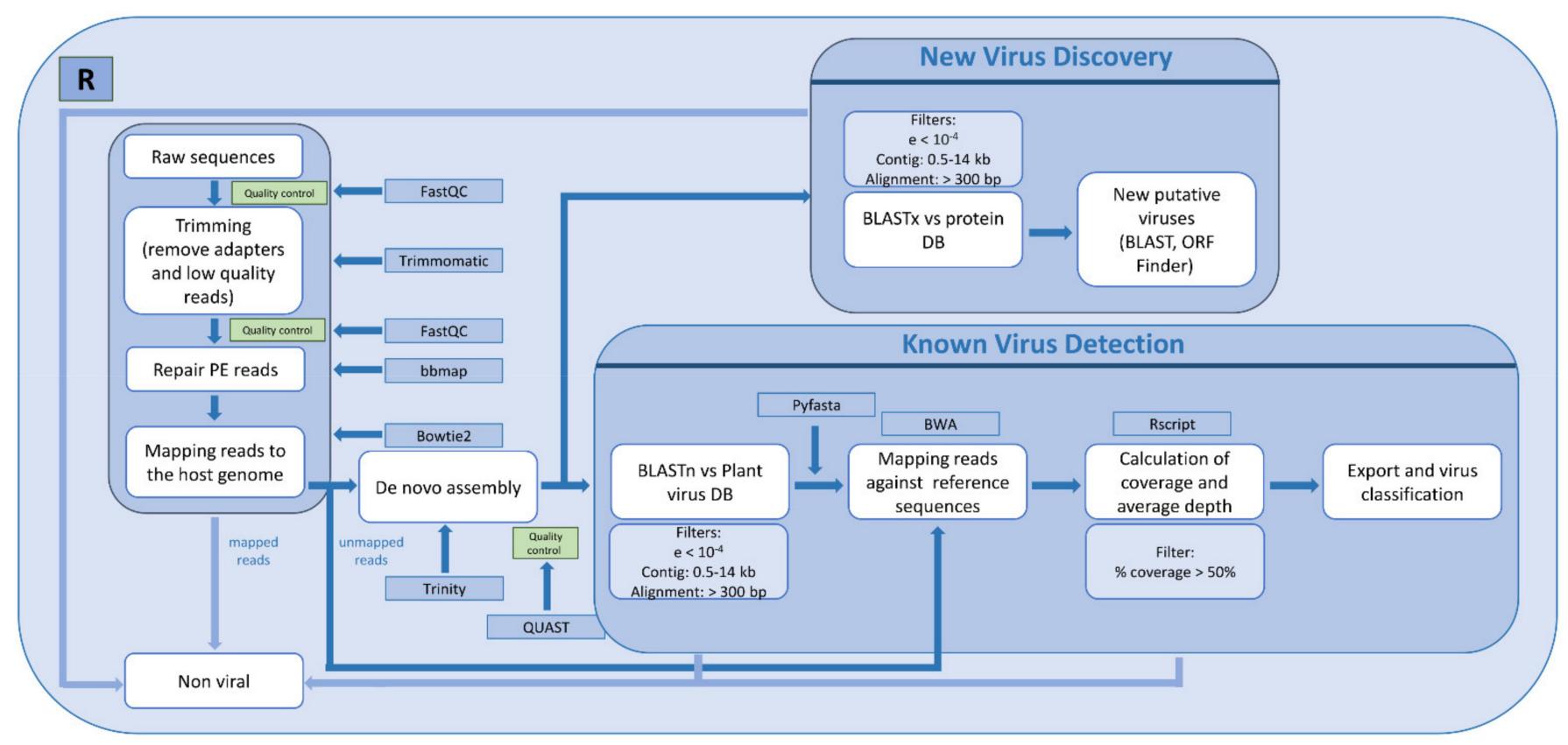

Figure 1. Bioinformatic workflow for the detection of known viruses and for novel virus discovery. Schematic representation of the bioinformatics pipeline followed in this work implemented in the R language. Specific programs (blue rectangles) used for each step (white rectangles) are indicated; applied filters are framed in light blue rectangles.

\subsection{Conventional RT-PCR and $q R T-P C R$}

All viruses were detected in individual samples by qRT-PCR, except southern tomato virus (STV), which was detected by conventional RT-PCR using the primer pair described in Table S2, Expand Reverse Transcriptase (Roche, Basel, Switzerland) and NXT Taq PCR Kit (EURx, Gdańsk, Poland) according to the manufacturer's instructions. Primers and probes for PepMV were published elsewhere [25]. For the other viruses, forward and reverse primers, together with TaqMan probes, were designed to target conserved regions of the CP gene, except for tomato fruit blotch virus (ToFBV) for which we used the RdRp gene, using the PrimerQuest Tool from IDT (https: / / eu.idtdna.com; acceded on September 2020). The specificity of all the primers and probes was confirmed in silico by a BLASTn search against the NCBI database. Primers' and probes' sequence information and the length of the amplicons are detailed in Table S2. For virus detection by qRT-PCR, the KAPA PROBE FAST One-Step qRT-PCR kit (Roche, Basel, SZ) was used. Each 10- $\mu$ L reaction consisted of $5 \mu \mathrm{L}$ of $2 \times$ Master Mix, $0.2 \mu \mathrm{L}$ of forward/reverse primers $(10 \mu \mathrm{M})$ and probe $(10 \mu \mathrm{M}), 0.2 \mu \mathrm{L}$ of $50 \times$ RT-Mix, $0.2 \mu \mathrm{L}$ of $50 \times$ ROX high, $2 \mu \mathrm{L}$ of DEPC-treated water and $2 \mu \mathrm{L}$ of RNA $(20 \mathrm{ng} / \mu \mathrm{L})$. The performance of the primers/probe pairs was determined by 
calculating the PCR amplification efficiency of the reaction from a standard curve of five 1:10 serial dilutions of the pooled total RNA sample (200 ng/ $\mu \mathrm{L})$ (Table S2).

\section{Results}

\subsection{HTS Using Two Different RNA Inputs: Total RNA and dsRNA}

Twenty samples from leaves of tomato plants exhibiting virus-like symptoms were collected from 2015 to 2020 from different locations in the South of Spain and Portugal (Table 1). The sampled plants exhibited a wide range of disease symptoms suggestive of viral infection, i.e., vein clearing, leaf distortion, leaf curling, necrotic spots or mosaics on leaves (Table 1). Figure 2 shows representative examples of symptoms found in two different greenhouses, displaying fruit blotching, uneven ripening and necrosis. From these samples, we prepared two different RNA inputs. Total RNA was purified from individual samples and then pooled; dsRNA was extracted in a single preparation from an equivalent pool of samples. We sequenced two different libraries from the total RNA pool, representing two technical replicates (Tom1 and Tom2) and one from the dsRNA extraction (TomDS).

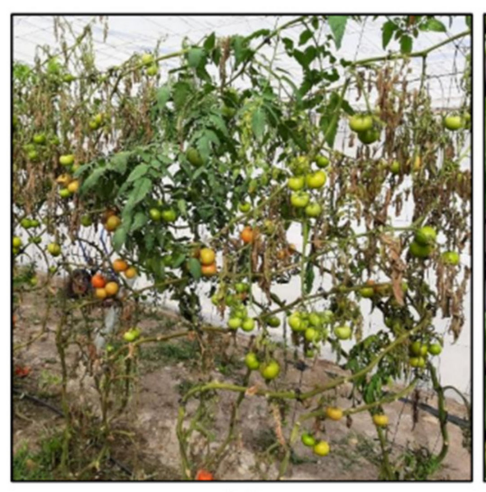

(A)

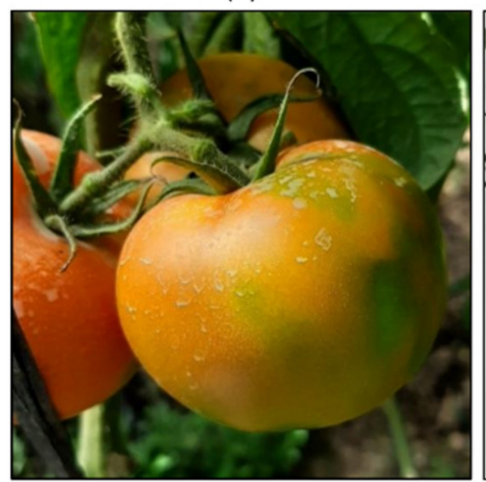

(B)

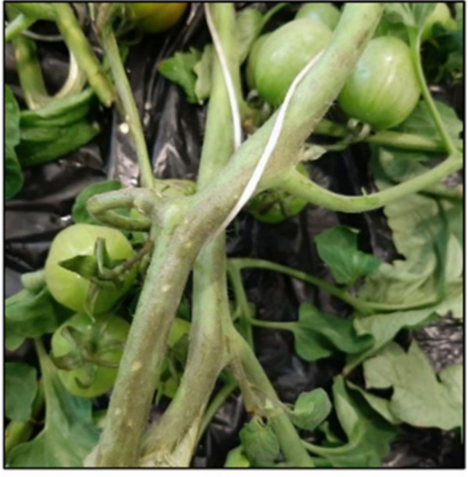

(C)

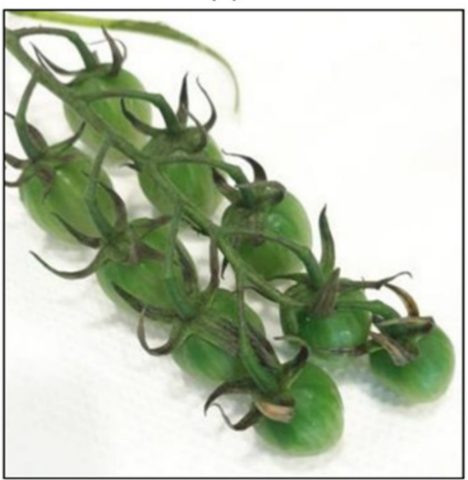

(D)

Figure 2. Tomato plants and fruits exhibiting virus-like symptoms. (A,B) correspond to the greenhouse where sample R19-07 was collected in Murcia. Tomato fruits exhibited fruit blotching and discoloration. (C,D) correspond to another greenhouse in Almería where sample R19-12 was collected, and tomato plants exhibited necrosis.

After sequencing the three libraries, we obtained 86,284,538, 84,739,174 and 64,540,826 reads for Tom1, Tom 2 and TomDS, respectively (Table 2). The raw reads were analyzed following the pipeline described in Figure 1. These were trimmed and filtered to remove low-quality bases, and tomato-derived sequences were extracted by mapping against the tomato genome (Table 2). As expected, the percentage of reads mapping to the plant genome was much lower using dsRNA ( $25.7 \%$ of the clean reads) than using total RNA as the input (around $48 \%$ of the clean reads) (Table 2). Hence, a total of 44,121,432, 43,524,150 and $47,320,422$ filtered reads corresponding to $51.9 \%, 52.1 \%$ and $74.3 \%$ of the clean reads 
were further used for virus identification in Tom1, Tom2 and TomDS, respectively (Table 2). Although the number of raw reads sequenced for the two total RNA samples was higher than for the dsRNA sample (around $80 \mathrm{M}$ compared to around $60 \mathrm{M}$ ), the number of reads after the application of different quality filters was similar for the three libraries (Table 2).

Table 2. Summary of sequencing and mapping results.

\begin{tabular}{ccccccc}
\hline & \multicolumn{2}{c}{ Tom1 } & \multicolumn{2}{c}{ Tom2 } & \multicolumn{2}{c}{ TomDS } \\
\hline & Reads & \% & Reads & \% & Reads & $\%$ \\
\hline Raw reads & $86,284,538$ & & $84,739,174$ & & $64,540,826$ & \\
Clean reads & $85,026,574$ & 98.54 & $83,516,356$ & 98.56 & $63,715,596$ & 98.72 \\
Host mappings & $40,905,042$ & 48.11 & $39,992,206$ & 47.89 & $16,395,174$ & 25.73 \\
Filter reads & $44,121,532$ & 51.89 & $43,524,150$ & 52.11 & $47,320,422$ & 74.27 \\
Viral contigs & 63 & & 51 & & 55 & \\
Unique viruses & 7 & & 7 & & 6 & \\
Viral reads & $6,790,296$ & 7.99 & $7,159,776$ & 8.57 & $20,491,882$ & 32.16 \\
\hline
\end{tabular}

\subsection{Comparison of Viral Species Found in Two Technical Replicates Using Total RNA as the Input}

In order to evaluate the reproducibility of the library construction and sequencing, the results from the two independent libraries, Tom1 and Tom2, were compared. The filtered reads were de novo assembled, and long contigs were mapped by BLASTn against our own plant virus database (Figure 1 and Table 2). After filtering the BLASTn results, we obtained a total of 63 and 51 contigs, with an average length of $2788 \mathrm{nt}$ and $3076 \mathrm{nt}$, that mapped to viral sequences for Tom 1 and Tom2, respectively (Table 2). To ensure high confidence in the detection of viruses, we set a minimum threshold of the assembled contig of $500 \mathrm{nt}$ in length. In both replicates, we identified the same seven virus species (Table 3). No novel viruses were found by BLASTx using our pipeline.

Table 3. Summary of mapping of reads against identified viral genomes.

\begin{tabular}{|c|c|c|c|c|c|c|c|c|c|c|c|c|c|}
\hline \multirow{2}{*}{ Virus } & \multirow{2}{*}{ Accession } & \multirow{2}{*}{ Genome } & \multirow{2}{*}{ Segment } & \multirow{2}{*}{$\begin{array}{c}\text { Ref. } \\
\text { Length }\end{array}$} & \multicolumn{3}{|c|}{ Tom1 } & \multicolumn{3}{|c|}{ Tom2 } & \multicolumn{3}{|c|}{ TomDS } \\
\hline & & & & & Reads & AD & PC & Reads & AD & PC & Reads & AD & PC \\
\hline OLV1 & DQ083996 & (+)ssRNA & & 3702 & 390 & 9 & 97.97 & 364 & 9 & 89.68 & 678 & 590 & 0.62 \\
\hline TYLCV & HF548826 & $(+)$ ssDNA & & 2787 & 1694 & 65 & 100 & 1596 & 60 & 99.64 & 1344 & 69 & 90.17 \\
\hline ToCV & $\begin{array}{l}\text { KF018280 } \\
\text { KJ815045 }\end{array}$ & $(+)$ ssRNA & $\begin{array}{l}\text { RNA1 } \\
\text { RNA2 }\end{array}$ & $\begin{array}{l}8596 \\
8249\end{array}$ & $\begin{array}{l}1106 \\
2736\end{array}$ & $\begin{array}{l}14 \\
42\end{array}$ & $\begin{array}{l}96.92 \\
99.33\end{array}$ & $\begin{array}{l}1076 \\
2794\end{array}$ & $\begin{array}{l}15 \\
43\end{array}$ & $\begin{array}{l}94.16 \\
99.52\end{array}$ & $\begin{array}{l}222,112 \\
235,672\end{array}$ & $\begin{array}{l}3441 \\
3759\end{array}$ & $\begin{array}{l}98.15 \\
99.79\end{array}$ \\
\hline STV & KT438549 & dsRNA & & 3463 & 1782 & 63 & 98.84 & 1812 & 64 & 98.64 & $3,459,440$ & 7319 & 99.19 \\
\hline ToFBV & $\begin{array}{l}\text { MK517477 } \\
\text { MK517478 } \\
\text { MK517479 } \\
\text { MK517480 }\end{array}$ & $(+)$ ssRNA & $\begin{array}{l}\text { RNA1 } \\
\text { RNA2 } \\
\text { RNA3 } \\
\text { RNA4 }\end{array}$ & $\begin{array}{l}5811 \\
3643 \\
2872 \\
1946\end{array}$ & $\begin{array}{l}39,452 \\
17,810 \\
72,830 \\
47,102\end{array}$ & $\begin{array}{c}878 \\
626 \\
2096 \\
2938\end{array}$ & $\begin{array}{c}99.78 \\
99.75 \\
99.51 \\
100\end{array}$ & $\begin{array}{l}41,498 \\
17,760 \\
81,684 \\
51,060\end{array}$ & $\begin{array}{c}930 \\
628 \\
2417 \\
3158\end{array}$ & $\begin{array}{c}99.78 \\
99.45 \\
99.65 \\
100\end{array}$ & $\begin{array}{c}255,152 \\
79,414 \\
500,460 \\
317,660\end{array}$ & $\begin{array}{l}5665 \\
2892 \\
6360 \\
7309\end{array}$ & $\begin{array}{c}99.88 \\
99.56 \\
99.93 \\
100\end{array}$ \\
\hline PepMV & NC_004067 & (+)ssRNA & & 6450 & $6,431,722$ & 7687 & 100 & $6,809,266$ & 7686 & 100 & $15,351,220$ & 7831 & 100 \\
\hline LRNV & $\begin{array}{l}\text { NC_006051 } \\
\text { NC_006052 } \\
\text { NC_-006053 } \\
\text { NC_006054 }\end{array}$ & $(-)$ ssRNA & $\begin{array}{l}\text { RNA } 1 \\
\text { RNA } 2 \\
\text { RNA } 3 \\
\text { RNA } 4\end{array}$ & $\begin{array}{l}7651 \\
1830 \\
1527 \\
1417\end{array}$ & $\begin{array}{c}13,116 \\
17,546 \\
108,412 \\
34,598\end{array}$ & $\begin{array}{c}223 \\
1258 \\
6655 \\
3226\end{array}$ & $\begin{array}{l}99.76 \\
99.89 \\
98.76 \\
99.86\end{array}$ & $\begin{array}{l}10,716 \\
15,668 \\
95,402 \\
29,080\end{array}$ & $\begin{array}{c}183 \\
1124 \\
6507 \\
2749\end{array}$ & $\begin{array}{l}99.48 \\
99.95 \\
99.41 \\
98.52\end{array}$ & $\begin{array}{c}14,738 \\
10,512 \\
38,700 \\
4780\end{array}$ & $\begin{array}{c}258 \\
758 \\
3458 \\
462\end{array}$ & $\begin{array}{l}99.12 \\
99.89 \\
97.12 \\
96.47\end{array}$ \\
\hline
\end{tabular}

AD: average read depth; PC: percentage of reference sequence covered by reads.

To calculate the average sequencing depth and the genome coverages, the filtered reads were mapped against the reference sequences of the identified viruses. In the cases where multiple accessions were found for the same virus species, the accession of the reference sequence used to map the reads was randomly selected. Viral reads constituted $7.99 \%$ and $8.57 \%$ of the clean reads for Tom 1 and Tom2, respectively (Table 2). The number of reads mapping to viral genomes varied from 390 (Tom1) and 364 (Tom2) reads, counted for olive latent virus 1 (OLV1), to 6,431,722 (Tom1) and 6,809,266 (Tom2), for PepMV (Table 3). The average sequencing depth varied from nine for OLV1 in either Tom1 and Tom2 to $\sim 7690$ for PepMV in either Tom1 and Tom2 (Table 3). The lowest percentage of coverage along the corresponding viral genome was found for OLV1 $(97.97 \%$ in Tom1 and 
89.68\% in Tom2) and RNA1 from ToCV (96.92\% in Tom1 and 94.16\% in Tom2) (Table 3). For the other virus species, the percentage of coverage was higher than $98 \%$ (Table 3 ). The nucleotide sequence identity among the viruses found in the two replicates was higher than $98.9 \%$ (Table S1). Overall, our results indicate that reproducibility using total RNA after rRNA depletion is very high, as no significant differences were observed among the results obtained here for the two replicates.

\subsection{Viral Species Found Using Total RNA or dsRNA as the Input}

Procedures for sample preparation and RNA extraction for dsRNA and total RNA were obviously different, but the amount of plant material used for both methods was the same, allowing some comparisons. Since Tom 1 and Tom 2 are almost identical replicates, only the comparison between TomDS and Tom1 is described. Fifty-five assembled contigs, with an average length of $3698 \mathrm{nt}$, derived from TomDS, mapped with our plant virus database, representing six virus species previously found in the analysis of the total RNA sample (Tables 2 and 3). The virus species not detected using dsRNA as the input was OLV1, although we found some mappings when reads were aligned against the OLV1 reference sequence (Table 3). For TomDS, the number of reads mapping to the identified reference virus sequences was substantially higher compared to the number of reads in Tom 1 (32.16\% versus $7.99 \%$ ) (Table 2). This result was expected, as the dsRNA extraction method enriches preparations in virus-specific products, in this case in the replicative form of the ssRNA viruses [13]. Accordingly, the number of reads mapping to each viral genome, the average depth of sequencing and the percentage of the viral genome covered by the reads were similar or much higher for TomDS than for Tom1 (Table 3). The exceptions were TYLCV, for which the number of reads mapping to its genome and the average depth were slightly lower in TomDS (1344 and 69, respectively) than in Tom1 (1694 and 65, respectively), and RNAs 2, 3 and 4 from lettuce necrosis ringspot virus (LRNV), for which these numbers were significantly lower in TomDS than in Tom1 (Table 3). The nucleotide sequence identity between the viruses found in TomDS compared to Tom 1 varied from $96.2 \%$ for PepMV to 99.9\% for RNA4 from ToFBV (Table S1). In conclusion, the dsRNA-based method seemed to provide better enrichment in viral reads and the assembly of longer contigs than the total RNA-based method for RNA viruses, with some apparent exceptions.

\subsection{In Silico Analysis of the Minimum Sequencing Depth Needed to Detect the Less Abundant Viruses}

In an attempt to determine the minimum number of reads needed to detect the viruses infecting our tomato samples, we performed three different in silico simulations by decreasing the number of initial raw reads used in the bioinformatic analysis. For this, three subsets of raw data, consisting of 50\% (Subset 1), 37.5\% (Subset 2) and 25\% (Subset 3) of the original Tom 1 and TomDS reads were extracted randomly and analyzed following the same pipeline described previously (Tables 4 and S3). We next measured three parameters in these datasets: number of mapped reads, percentage of coverage and average read depth along the viral genomes.

Table 4. Summary of results obtained after subsetting the raw reads.

\begin{tabular}{|c|c|c|c|c|c|c|c|c|c|c|c|c|}
\hline & \multicolumn{4}{|c|}{ Subset $1(50 \%)$} & \multicolumn{4}{|c|}{ Subset $2(37.5 \%)$} & \multicolumn{4}{|c|}{ Subset $3(25 \%)$} \\
\hline & \multicolumn{2}{|c|}{ Tom1 } & \multicolumn{2}{|c|}{ TomDS } & \multicolumn{2}{|c|}{ Tom1 } & \multicolumn{2}{|c|}{ TomDS } & \multicolumn{2}{|c|}{ Tom1 } & \multicolumn{2}{|c|}{ TomDS } \\
\hline & Reads & $\%$ & Reads & $\%$ & Reads & $\%$ & Reads & $\%$ & Reads & $\%$ & Reads & $\%$ \\
\hline Subset & $40,000,000$ & & $30,000,000$ & & $30,000,000$ & & $22,500,000$ & & $20,000,000$ & & $15,000,000$ & \\
\hline Clean reads & $39,416,281$ & 98.54 & $29,616,416$ & 98.72 & $29,562,358$ & 98.54 & $22,212,742$ & 98.72 & $19,708,041$ & 98.54 & $14,809,024$ & 98.73 \\
\hline Host mappings & $19,544,446$ & 49.58 & $7,618,386$ & 25.72 & $14,223,278$ & 48.11 & $5,714,092$ & 25.72 & $9,483,289$ & 48.12 & $3,808,670$ & 25.72 \\
\hline Filter reads & $20,455,554$ & 51.90 & $21,998,030$ & 74.28 & $15,339,080$ & 51.89 & $16,498,650$ & 74.28 & $10,224,752$ & 51.88 & $11,000,354$ & 74.28 \\
\hline Viral contigs & 50 & & 56 & & 43 & & 40 & & 36 & & 40 & \\
\hline Unique viruses & 7 & & 6 & & 7 & & 6 & & 7 & & 6 & \\
\hline Viral reads & $3,033,136$ & 14.83 & $9,245,404$ & 42.03 & $2,275,725$ & 14.84 & $6,934,690$ & 42.03 & $1,515,690$ & 14.82 & $4,622,820$ & 42.02 \\
\hline
\end{tabular}


After the analysis of the different subsets (Tables 4 and S3), we found the same viruses as when using the full datasets (seven species for Tom 1 and six for TomDS), but there were differences in the estimated parameters. The percentage of unmapped reads against the tomato genome did not vary with the subsetting either for Tom1 or TomDS (Tables 2 and 4). Although the number of contigs mapping to the plant virus database decreased with the subsets, the average contig length was not always lower, with the Subset 3 in Tom1 being higher (3167 nt) than for the full dataset in Tom1 (2788 nt). The number of reads mapping to the reference viruses decreased across the three subsets (Tables 2 and 4); however, the percentage of the mapped reads was maintained among the three different subsets as compared to the full datasets (approximately $14.82 \%$ for Tom 1 and $42 \%$ for TomDS) (Table 4 ). In general, the average read depth decreased across the different subsets, with the only exception being PepMV in TomDS, for which the average depth was maintained across the subsets (Figure 3 and Table S3). For the viruses in which the percentage of coverage using the full datasets was higher than $89 \%$, there were only slight differences in the percentage of coverage when decreasing the sequencing depth (Figure 3 and Table S3). Four additional subsets, consisting of $12.50 \%$ (Subset 4), $6.25 \%$ (Subset 5), 3.13\% (Subset 6) and 1.5\% (Subset 7), were made (Table S3). For OLV1 in Tom1 and using $12.5 \%$ (Subset 4 ) of the total reads, 25 reads were mapped to the viral genome, with an average depth of 1.57 (Table S3), but no contigs longer than the minimum threshold could be assembled (Table S3). For TYLCV in TomDS, decreasing the raw reads to $3.13 \%$ (Subset 6) resulted in 38 reads mapping to its viral genome, with an average depth of 3.58 (Table S3), but again no contigs could be assembled. This in silico analysis was repeated using two new random subsets of 37.5\% (Subset 2) and 25\% (Subset 3) of the full datasets obtaining reproducible results (Table S3). In conclusion, to detect viruses infecting our sample pool, we could have decreased the initial sequencing depth to $25 \%$ of the full datasets for the total RNA input, from $80 \mathrm{M}$ to $20 \mathrm{M}$, and to $6.25 \%$ for the dsRNA input, from $60 \mathrm{M}$ to $3.75 \mathrm{M}$, and still identify the same virus species.

\subsection{Viruses Already Reported to Infect Tomato Plants in Spain}

Four viruses that are frequently reported in tomato crops were detected in our samples: PepMV, STV, ToCV and TYLCV. To identify their closest virus isolates in the databases, assembled contigs were further aligned by BLASTn against the specific virus taxon using the NCBI nr/nt database. We performed qRT-PCR or conventional RT-PCR to determine the presence of these viruses in the individual samples used for the pools (Tables 1 and S2). PepMV (family Alphaflexiviridae, genus Potexvirus), a (+)ssRNA virus, was the most abundant virus in our sample pools, with more than $28 \mathrm{M}$ reads across the three datasets: more than $13 \mathrm{M}$ reads in both total RNA samples, and more than $15 \mathrm{M}$ reads in the dsRNA sample (Table 3). Thirteen contigs, almost covering the complete genome with the typical genome features described for PepMV, were determined from the three samples, all of them mapping with the highest identity against both $\mathrm{CH} 2$ and EU strains. We detected PepMV using qRT-PCR in 19 out of 20 samples, 13 of them in mixed infections with viruses from both strains, and the other six infected only with viruses from the $\mathrm{CH} 2$ strain, which seemed to accumulate at higher concentrations in most of the samples (Table 1).

STV (family Amalgaviridae, genus Amalgavirus), which possesses a dsRNA genome, was the second virus for which a higher number of reads mapped along its genome in the dsRNA sample (more than $3 \mathrm{M}$ ), although very few viral reads were obtained from the total RNA samples (1782 in Tom1 and 1812 in Tom2) (Table 3). We were able to assemble almost the full viral genome from reads derived from the three datasets, obtaining three different contigs, one per dataset, that shared a percentage of identity higher than $99.9 \%$ among them (Table S1). These sequences contained the two overlapping ORFs described for STV: a putative $\mathrm{CP}$ and the RdRp protein. All the contigs showed a nucleotide identity of more than $99.9 \%$ with a sequence from Canada (MK610257.1). STV was detected in 16 out of 20 individual samples using conventional RT-PCR (Table 1). 
Average read depth of Tom1 reads

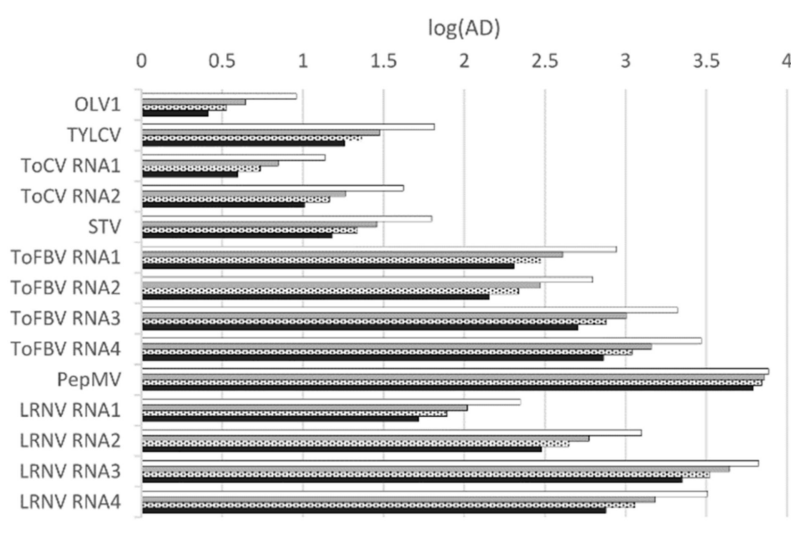

Average read depth of TomDS reads

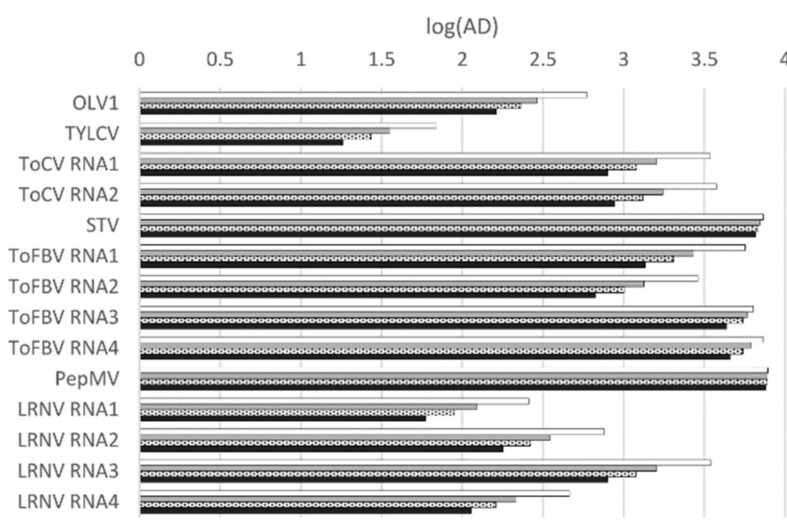

(A)
Percentage of coverage of Tom1 reads

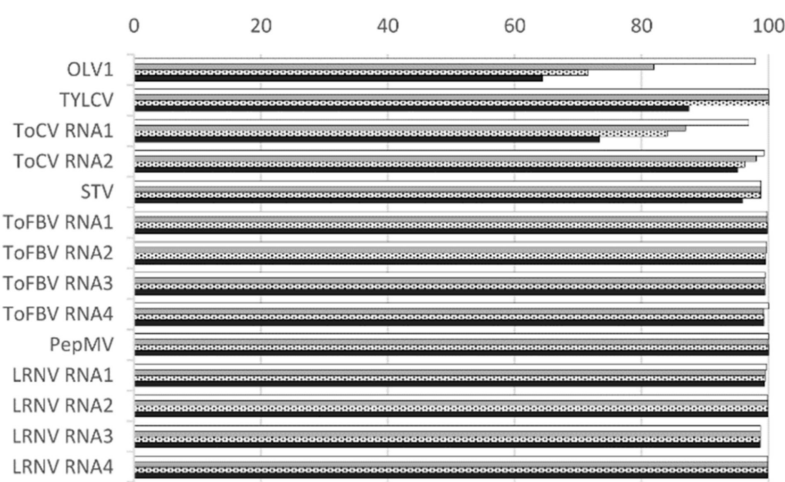

Percentage of coverage of TomDS reads

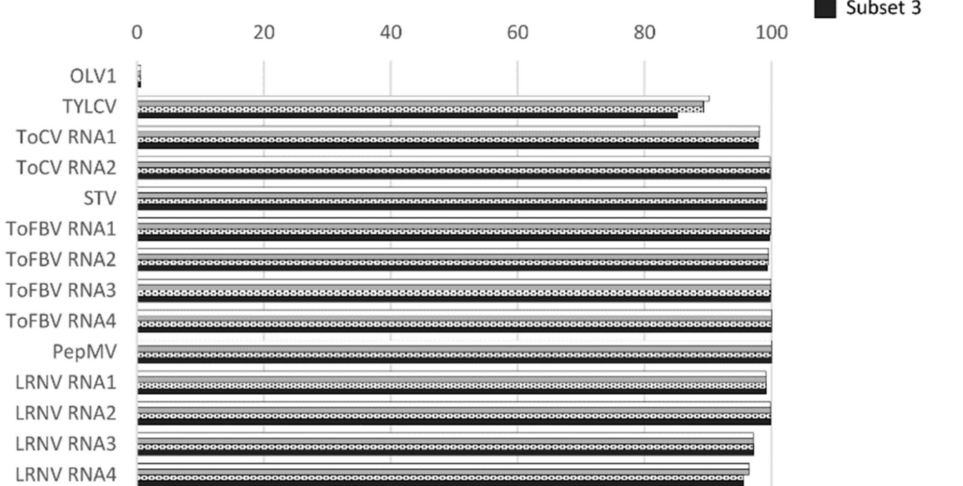

(B)

Figure 3. Comparison of average read depth and percentage of viral genomes covered by reads in Tom1 and TomDS. (A) Bar plots showing the logarithm of the average read depth for each viral genome in Tom1 (upper) and TomDS (bottom). (B) Bar plots showing the percentage of viral genomes covered by reads in Tom1 (upper) and TomDS (bottom). Full datasets: white bars; Subset 1: gray bars; Subset 2: dotted bars; Subset 3: black bars.

ToCV (family Closteroviridae, genus Crinivirus), with a bipartite (+)ssRNA genome, was the fourth most abundant virus among the seven viruses identified, with 457,789 reads in TomDS and around hundred times less in the total RNA samples (3842 in Tom1 and 3870 in Tom2) (Table 3). A unique 8585-nt contig, covering almost the complete genome of RNA 1 from ToCV, was determined from the dsRNA sample. It shared $99.9 \%$ nucleotide identity with RNA 1 from the ToCV isolate from Spain (KJ200304.1). Multiple contigs were determined from Tom1 and Tom2 with a length shorter than $5777 \mathrm{nt}$, showing the highest identity with the same ToCV strain. Three contigs, ranging from $8195 \mathrm{nt}$ to $8239 \mathrm{nt}$ in length, that corresponded to the near complete genome of RNA 2 were determined from the three datasets respectively. These contigs showed more than $99.8 \%$ nt identity with RNA2 from the ToCV isolate from Spain (KJ200305.1). ToCV was detected in eight out of 20 individual samples by qRT-PCR (Table 1 ).

TYLCV (family Geminiviridae, genus Begomovirus), a (+) ssDNA virus, was detected using the two different RNA inputs but, with the exception of OLV1, it was the virus for which we obtained the lowest number of reads mapping to its genome (around 1694 and 1596 in Tom 1 and Tom 2 and 1344 in TomDS) (Table 3). Different contigs ranging from $685 \mathrm{nt}$ to $2212 \mathrm{nt}$ were found to derive from TYLCV across the three datasets. A BLASTn analysis of these sequences revealed a nucleotide similarity above $97 \%$ with other TYLCV sequences belonging to the Israel strain (TYLCV-IL). No insertion characterizing the TYLCV-IS76 
isolates was detected in the non-coding intergenic region of these sequences [26]. Based on qRT-PCR of individual samples, TYLCV was detected in seven out of 20 samples.

\subsection{Viruses Not Previously Reported to Infect Tomato Plants in Spain}

We also identified three virus species that, to our knowledge, were not previously reported or not frequently reported to infect tomato plants in Spain: LRNV, OLV1 and ToFBV $[27,28]$. To further understand these observations, we determined the consensus sequences from the reads mapping to virus reference genomes. As for the other viruses, we detected the presence of these three viruses in the individual samples using qRT-PCR (Tables 1 and S2).

LRNV (family Aspiviridae, genus Ophiovirus) is a four-segmented (-)ssRNA virus, and was detected in the pooled sample using the two RNA extraction approaches. We determined the consensus sequences for the four LRNV RNA segments (RNA 1 to 4). The RNA 1 consensus sequence (MW594439) was 7604 nt in length, covering $99 \%$ of the reference segment (AY535016), sharing a 99.4\% identity with it. This RNA comprises two ORFs, which are $582 \mathrm{nt}$ and $6834 \mathrm{nt}$ in length, respectively. The RNA 2 consensus sequence (MW594440) was $1826 \mathrm{nt}$ in length, lacking only $4 \mathrm{nt}$ at the $5^{\prime}$ end compared to the reference RNA2 sequence (AY535017). Our sequence shared $99.2 \%$ at the nt level and $99.1 \%$ at the amino acid level with its RNA2 reference. The RNA 3 consensus sequence (MW594441) was $1505 \mathrm{nt}$ (lacking $22 \mathrm{nt}$ in total from both ends compared to the reference sequence, AY535018). Its vcRNA has one ORF of $1311 \mathrm{nt}$ that encodes the CP protein. The $\mathrm{CP}$ showed a $99.1 \%$ amino acid identity with the $\mathrm{CP}$ of this reference isolate. The consensus sequence of RNA 4 (MW594442) was $1378 \mathrm{nt}$ in length, covering $97 \%$ of the LRNV RNA 4 genome (AY535019) and sharing a $99.1 \%$ of nucleotide identity. The presence of LRNV was confirmed in the pooled sample as well as in four out of 20 individual samples by qRT-PCR using specific primers and probes targeting the $\mathrm{CP}$ (Tables 1 and S2). The samples in which the virus was detected were from crops in Almería (Southeastern Spain) collected in 2015, 2019 and 2020, with the highest accumulation of this virus in samples collected in 2020 (Table 1), as determined by qRT-PCR.

ToFBV (family Kitaviridae, genus Blunervirus) is a four-segmented (+)ssRNA virus, recently discovered to infect tomato plants in Italy and Australia [27]. The consensus sequences were determined for the four RNAs, and these were $5779 \mathrm{nt}$ (RNA1, MW594435), 3586 nt (RNA2, MW594436), 2869 nt (RNA3, MW594437), and 1926 nt (RNA4, MW594438) in length, covering the full length of the four ToBFV RNA segments of isolate Fondi2018 from Italy (MK517477, MK517478, MK517479, and MK517480). The percentages of nucleotide identity of the consensus sequences against the reference sequences were $98.8 \%$, $98.8 \%, 99.6 \%$ and $99 \%$ for RNAs 1 to 4 , respectively. Five out of 20 individual samples were positive according to qRT-PCR using specific primers and probes targeting a conserved region of the RdRp (RNA1) (Tables 1 and S2). Four samples were collected in Murcia in 2016, 2017 and 2019, and one in Portugal in 2015 (Table 1).

OLV1 (family Tombusviridae, genus Alphanecrovirus), with a (+)ssRNA genome, was the least abundant virus in our datasets (Table 3), and was only detected using the total RNA extraction method. Unlike the other two previous viruses, we compared contigs against the NCBI database to describe this virus, as the determined consensus sequence contained a very high proportion of unknown nucleotides. Four contigs, ranging from $641 \mathrm{nt}$ to $1847 \mathrm{nt}$, were determined, covering a partial sequence of the RdRp protein and the full sequence of the CP. The contig covering the full CP gene shared $95.2 \%$ of nucleotide identity with isolate OLV1 Anhui from China (MK376952.1) and 98.1\% amino acids with isolate A4P2 from Portugal (AHE40781.1). Two out of 20 samples were infected with OLV1 by qRT-PCR using specific primers and probes targeting the CP; both samples were collected in 2015 in Almería and Portugal, respectively (Table 1). 


\section{Discussion}

HTS was used to identify viruses present in a pool of twenty samples of tomato leaves showing virus-like symptoms collected in areas where tomato cultivation is very important. We first assessed the reproducibility of the sequencing method by generating a replicate of the total RNA with a ribosomal depletion sample; after analysis, we did not find important differences between replicates in terms of virus species detected or the number of reads mapping to each reference virus genome. In contrast, our data suggest that the extraction method seems to have an impact on the viruses that could be identified by HTS, in agreement with previous reports. For instance, Kutnjak et al. [10] compared siRNA and VANA approaches and found that both provided highly similar viral mutational landscapes, but VANA allowed for better recovery of complete viral genomes and detection of recombinant genomes [10]. In another example, rRNA-depleted total RNA was found to be superior to siRNA for the identification of citrus tristeza virus (CTV) (family Closteroviridae, genus Closterovirus) and citrus dwarfing viroid (CDVd) (family Pospiviroidae, genus Apscaviroid) infecting grapefruit, rendering better coverage for CTV but not for the viroid [29]. Another study showed that the performance of these two approaches tended to be virus-dependent, but in general longer contigs and higher genome coverage were obtained by rRNA-depleted total RNA than by sRNA sequencing [11]. Ma et al. [12] compared dsRNA and VANA approaches in assessing the virus diversity in wild plant populations. In their experimental system, the dsRNA approach revealed a broader and more comprehensive diversity for RNA viruses than VANA [12]. Gallo-García et al. [30] used total RNA and dsRNA as inputs to assess the virus populations in cape gooseberry (Physalis peruviana L.). They found higher sequence diversity for a specific virus species in total RNA as compared to dsRNA, but the total RNA extraction method failed to detect viruses present at low concentrations [30]. Hence, these and other authors have suggested the use of rRNA-depleted total RNA and dsRNA as complementary methods to obtain a comprehensive picture of the viruses present in a field sample $[3,30]$. In our case, and contrary to what was described by Gallo-Garcia et al. [30], rRNA-depleted total RNA performed better because seven, as opposed to six, viral species were detected using rRNA-depleted total RNA versus dsRNA. However, we cannot rule out the possibility that this difference may be due to the different pooling strategies used here. Although there were reads mapping to OLV1 in the dsRNA sample, the percentage of read coverage along the viral genome was only $0.62 \%$ (Table 3 ). This coverage was rendered by a fragment of $22 \mathrm{nt}$ inside a read of around $109 \mathrm{nt}$ that had been sequenced many times, hence the high average depth found (Table 3). However, this read had no significant hits against the NCBI database, not even with OLV1. Both methods allowed almost complete coverage of the genomes of the most abundant viruses (PepMV, STV, LRNV, ToFBV), however, the average depth was higher using the dsRNA approach in most of the cases. Interestingly, we noticed that total RNA generated more reads for LRNV, a (-)ssRNA virus, and for TYLCV, a ssDNA virus. This latter result was not surprising, as during TYLCV replication no dsRNA replicative intermediates are formed [31].

Some previous works have discussed the possibility of the application of HTS for routine plant virus diagnostics, mentioning different parameters to take into consideration, such as sensitivity, specificity and reproducibility [32]. Al Rwahnih et al. [33] compared the sensitivity of HTS to biological indexing for plant material certification in grapevines and concluded that it may reach a high sensitivity level, with the advantage of being time effective as compared to conventional methods [33]. In addition, Candresse et al. [34] used HTS to detect sugarcane white streak virus (family Geminiviridae, genus Mastervirus) in two quarantined sugarcane plants, showing the importance of including this method to assess plant health status [34]. However, sequencing large numbers of individuals or samples, which is often needed to obtain an overview of the plant viruses present in a population, is still challenging, despite falling HTS costs over the last decade. Furthermore, the need for a high-quality RNA input for library preparation and the complexity of the bioinformatics analyses should be taken into consideration when approaching HTS 
studies. One of the main methodological decisions for pool sequencing is the balance between the number of samples to be pooled and the sequencing depth required to detect all viruses present in the pool. According to the literature, the pool composition of different metagenomic studies for plant viromes varied from four to 50 individual samples per pool [9,12,35-39]. Skums et al. [40] provided a mathematical approach for a pooling strategy for the massive sequencing of human viruses, since the complex nature of these samples imposed restrictions on the pool design [40]. Here, we tried to address the problem of minimum reads needed to detect the less abundant viruses in a pool by following an in silico approach. The libraries for the two strategies used were sequenced with a different initial sequencing depth: $80 \mathrm{M}$ for the total RNA replicates and $60 \mathrm{M}$ for the dsRNA sample. In theory, this sequencing depth would correspond to $4 \mathrm{M}$ reads per sample for the total RNA and $3 \mathrm{M}$ reads per sample for the dsRNA input. We have demonstrated that we were able to detect the same viruses from the full datasets and from the three different subsets composed of $50 \%, 37.5 \%$ and $25 \%$ of the initial reads, and even for two additional subsets composed of $12.5 \%$ and $6.25 \%$ of the initial reads in the case of dsRNA. The less abundant viruses identified in the full datasets were OLV1 in the case of the total RNA replicates and TYLCV in the case of the dsRNA sample. However, the percentage of coverage decreased in the subsets, so the level of confidence in the detection of these viruses also decreased. TYLCV and OLV1 were detected in seven and two individual samples, respectively, and at very high Ct values (higher than 28 in most of the samples), suggesting the low accumulation of these viral RNAs in the pooled sample. In conclusion, we believe that $1.5 \mathrm{M}$ reads per sample could have been used for assessing the tomato virome when using rRNA-depleted total RNA. In the case of using dsRNA as the input, a minimum of $0.2 \mathrm{M}$ reads per sample could have been used as the initial sequencing depth. Generalizing these results is difficult, as different crops under different environmental conditions infected by different sets of viruses may require other sequencing depths. Using a low number of reads in a de novo assembly, it is possible that bioinformatics analysis fails to build significantly long contigs; hence, some virus derived reads could be disregarded during the bioinformatic analysis. The high output noise generated by this technique and/or possible contaminations demonstrate the necessity of using conventional detection methods as a complementary tool for the confirmation of the presence of a virus.

Three viruses known to infect tomato plants, and to induce important crop losses, were detected in our samples. PepMV was detected in 19 samples by means of qRTPCR, confirming the HTS results. Two strains, EU and $\mathrm{CH} 2$, were detected in mixed infections in 13 out of 19 PepMV-infected samples. This high incidence could be due to the generalization of cross-protection as a means of disease control in the South of Spain [41], though generalized single and mixed infections of PepMV isolates of these two strains were already reported in the region before the extended use of cross-protection [42]. The detection here of ToCV and TYLCV is not surprising as both are prevalent viruses across the southern and eastern regions of Spain and both are transmitted by whiteflies [43-46]. A survey of STV incidence was conducted on different tomato fields in Spain in 2018, revealing that STV was widespread [47]. Moreover, this virus was detected in different tomato varieties and nurseries, but STV-infected tomato plants did not show any disease symptoms [47]. Apart from the four viruses mentioned above, there are other viruses known to be widespread and of major concern for tomato plants, including, for instance, TSWV, potato virus $Y$, cucumber mosaic virus [1] and the emergent ToBRFV, but none of these were detected in our samples.

In addition to viruses frequently cited in tomato plants, three viruses that are seldom if ever cited to infect these species were detected in this study. The first report of LRNV was in lettuce (Lactuca sativa) crops in 1996, associated with lettuce ring necrosis disease. LRNV is transmitted by the soil-borne fungus Olpidium brassicae [48]. However, no additional information on the distribution and the epidemiological status of the virus could be found in the literature. Although in our study LRNV was detected in samples showing necrosis, vein clearing and yellow mosaic, these symptoms can be hardly associated with it, because 
it was detected in mixed infections in all the positive samples. OLV1 was isolated for the first time from olive trees in the Apulia region of Southern Italy [49]. Infected olive trees had normal flowers and fruits and did not show disease symptoms except for occasional fasciation and bifurcations of leaves and twigs [49]. Since then, OLV1 has been reported in different hosts in various countries [50,51], and in 2010 it was reported for the first time in tomato plants in Poland, associated with necrotic spots on the leaves [28]. The presence of this virus in the plants of different tomato cultivars was restricted to local lesions or to necrotic areas [28]. This may suggest that the surrounding crops may constitute the primary natural source of virus inoculum in the greenhouse-grown tomato, and that the daily manipulation of tomato plants by workers could play a key role in its spread. ToFBV is a new blunervirus that was recently reported in Italy and Australia, and it was associated with blotchy ripening and dimpling of the tomato fruits [27]. ToFBV could not be transmitted mechanically to either tomato or a set of various herbaceous plants, and thus Koch's postulates have not been fulfilled yet for this virus. Generally, kitaviruses share important epidemiological aspects such as symptomatology, lack of systemic movement and mite-mediated transmission [52].

The analysis of the individual samples, carried out to detect the seven viruses, revealed the extent of mixed infections, and the almost universal mixed infections of any of the viruses with $\mathrm{CH} 2$ and/or EU isolates of PepMV. Multiple viruses could infect a single plant; for instance, LRNV was detected in plants infected with OLV1, TYLCV and ToCV. ToFBV was detected in mixed infections with TYLCV and ToCV. Mixed infections can affect the virus's replication and movement competence, transmission capacity, virulence, host range and symptom severity [53]; therefore, more studies must be conducted to assess the impact of mixed infections in tomato and other crops. Mixed infections also prevented us from associating virus detection with disease symptoms-using the data collected during our sampling, no obvious correlation could be established between observed symptoms and the detection of any of the three viruses discussed above.

HTS is a very powerful technique for virus discovery and detection, and this emerged clearly from our study. We identified viruses that were present in tomato crops several years ago (samplings were conducted in 2015) but which remained unreported. The increased ability to detect new or infrequent viruses using this technique raises several questions relating to how to deal with them from a crop protection point of view, as well as the complexity of their biological characterization, particularly for the newly-identified plant viruses and viroids, and their impact at biosecurity, commercial, regulatory and scientific levels [54]. Here, we have reported for the first time the presence of OLV1 in tomato crops in Portugal and the South of Spain, and the presence of LRNV and ToFBV in tomato crops in the South of Spain. However, broader surveys are needed to assess the prevalence and potential impact of these viruses, including surveys of alternative hosts that may serve as virus reservoirs, in order to better understand their epidemiological status.

Supplementary Materials: The following are available online at https:/ / www.mdpi.com/article/10. 3390/microorganisms9051043/s1, Table S1. Comparison of percentage of identity of virus sequences among the three samples; Table S2. Primers and probes used for viral detection by qRT-PCR and conventional RT-PCR for STV; Table S3. Summary of results obtained after mapping the reads from different subsets against identified viral genomes.

Author Contributions: Conceptualization, A.M., M.A.A. and L.D.; formal analysis, A.M.; funding acquisition, Y.H.; methodology, A.M. and L.D.; project administration, Y.H.; resources, C.T. and R.N.S.; supervision, M.A.A. and L.D.; writing—original draft, A.M. and L.D.; writing-review and editing, A.M., M.A.A. and L.D. All authors have read and agreed to the published version of the manuscript.

Funding: This research has received funding from the European Union's Horizon 2020 research and innovation programme under the Marie Skłodowska-Curie grant agreement No 813542T. 
Data Availability Statement: Virus sequences were deposited in the GenBank database under the following accession number: ToFBV (MW594435, MW594436, MW594437 and MW594438 for RNA1, RNA2, RNA3 and RNA respectively and LRNV (MW594439, MW594440, MW594441 and MW594442 for RNA1, RNA2, RNA3 and RNA4 respectively). Raw reads were submitted to the Sequence Read Archive (SRA) under the ID numbers SRR14066946-SRR14066948. Main code was deposited in GitHub (https:/ /github.com/ldonaire/R_scripts/blob/main/Tomato_virus_pipeline_ -v1.R; accessed on May 2020).

Acknowledgments: We thank Mario Fon (mariogfon@gmail.com) for editing the manuscript.

Conflicts of Interest: The authors declare no conflict of interest.

\section{References}

1. Hanssen, I.M.; Lapidot, M. Major tomato viruses in the Mediterranean basin. In Advances in Virus Research; Elsevier: Amsterdam, The Netherlands, 2012; Volume 84, pp. 31-66, ISBN 0065-3527.

2. Woolhouse, M.E.J.; Gowtage-Sequeria, S. Host range and emerging and reemerging pathogens. Emerg. Infect. Dis. 2005, 11, 1842. [CrossRef] [PubMed]

3. Roossinck, M.J.; Martin, D.P.; Roumagnac, P. Plant virus metagenomics: Advances in virus discovery. Phytopathology 2015, 105, 716-727. [CrossRef] [PubMed]

4. Li, Y.; Jia, A.; Qiao, Y.; Xiang, J.; Zhang, Y.; Wang, W. Virome analysis of lily plants reveals a new potyvirus. Arch. Virol. 2018, 163, 1079-1082. [CrossRef]

5. Jo, Y.; Choi, H.; Kim, S.-M.; Kim, S.-L.; Lee, B.C.; Cho, W.K. The pepper virome: Natural co-infection of diverse viruses and their quasispecies. BMC Genom. 2017, 18, 1-12. [CrossRef]

6. Jo, Y.; Cho, W.K. RNA viromes of the oriental hybrid lily cultivar "Sorbonne". BMC Genom. 2018, 19, 748. [CrossRef] [PubMed]

7. Mutuku, J.M.; Wamonje, F.O.; Mukeshimana, G.; Njuguna, J.; Wamalwa, M.; Choi, S.-K.; Tungadi, T.; Djikeng, A.; Kelly, K.; Domelevo Entfellner, J.-B. Metagenomic analysis of plant virus occurrence in common bean (Phaseolus vulgaris) in Central Kenya. Front. Microbiol. 2018, 9, 2939. [CrossRef] [PubMed]

8. Xu, C.; Sun, X.; Taylor, A.; Jiao, C.; Xu, Y.; Cai, X.; Wang, X.; Ge, C.; Pan, G.; Wang, Q. Diversity, distribution, and evolution of tomato viruses in China uncovered by small RNA sequencing. J. Virol. 2017, 91. [CrossRef]

9. Ma, Y.; Marais, A.; Lefebvre, M.; Faure, C.; Candresse, T. Metagenomic analysis of virome cross-talk between cultivated Solanum lycopersicum and wild Solanum nigrum. Virology 2020, 540, 38-44. [CrossRef]

10. Kutnjak, D.; Rupar, M.; Gutierrez-Aguirre, I.; Curk, T.; Kreuze, J.F.; Ravnikar, M. Deep sequencing of virus-derived small interfering RNAs and RNA from viral particles shows highly similar mutational landscapes of a plant virus population. J. Virol. 2015, 89, 4760-4769. [CrossRef]

11. Pecman, A.; Kutnjak, D.; Gutiérrez-Aguirre, I.; Adams, I.; Fox, A.; Boonham, N.; Ravnikar, M. Next generation sequencing for detection and discovery of plant viruses and viroids: Comparison of two approaches. Front. Microbiol. 2017, 8, 1998. [CrossRef]

12. Ma, Y.; Marais, A.; Lefebvre, M.; Theil, S.; Svanella-Dumas, L.; Faure, C.; Candresse, T. Phytovirome analysis of wild plant populations: Comparison of double-stranded RNA and virion-associated nucleic acid metagenomic approaches. J. Virol. 2019, 94, e0146219. [CrossRef]

13. Valverde, R.A.; Nameth, S.T.; Jordan, R.L. Analysis of double-stranded RNA for plant virus diagnosis. Plant Dis. 1990, 74, 255-258.

14. Marais, A.; Faure, C.; Bergey, B.; Candresse, T. Viral double-stranded RNAs (dsRNAs) from plants: Alternative nucleic acid substrates for high-throughput sequencing. In Viral Metagenomics; Springer: Berlin/Heidelberg, Germany, 2018 ; pp. 45-53.

15. Bolger, A.M.; Lohse, M.; Usadel, B. Trimmomatic: A flexible trimmer for Illumina sequence data. Bioinformatics 2014, 30, 2114-2120. [CrossRef] [PubMed]

16. Bushnell, B. BBMap: A Fast, Accurate, Splice-Aware Aligner; Lawrence Berkeley National Lab.(LBNL): Berkeley, CA, USA, 2014.

17. Langmead, B.; Salzberg, S.L. Fast gapped-read alignment with Bowtie. Nat. Methods 2012, 9, 357. [CrossRef] [PubMed]

18. Haas, B.J.; Papanicolaou, A.; Yassour, M.; Grabherr, M.; Blood, P.D.; Bowden, J.; Couger, M.B.; Eccles, D.; Li, B.; Lieber, M. De novo transcript sequence reconstruction from RNA-seq using the Trinity platform for reference generation and analysis. Nat. Protoc. 2013, 8, 1494-1512. [CrossRef] [PubMed]

19. Altschul, S.F.; Gish, W.; Miller, W.; Myers, E.W.; Lipman, D.J. Basic local alignment search tool. J. Mol. Biol. 1990, 215 , 403-410. [CrossRef]

20. Camacho, C.; Madded, T.; Tao, T.; Agarwala, R.; Morgulis, A. BLAST ${ }^{\circledR}$ Command Line Applications User Manual; National Center for Biotechnology Information (US): Bethesda, MD, USA, 2018.

21. Li, W.; Godzik, A. Cd-hit: A fast program for clustering and comparing large sets of protein or nucleotide sequences. Bioinformatics 2006, 22, 1658-1659. [CrossRef]

22. Li, H.; Durbin, R. Fast and accurate short read alignment with Burrows-Wheeler transform. Bioinformatics 2009, 25, 1754-1760. [CrossRef]

23. Li, H.; Handsaker, B.; Wysoker, A.; Fennell, T.; Ruan, J.; Homer, N.; Marth, G.; Abecasis, G.; Durbin, R. The sequence alignment/map format and SAMtools. Bioinformatics 2009, 25, 2078-2079. [CrossRef] 
24. Li, H. Seqtk: A Fast and Lightweight Tool for Processing Sequences; Broad Inst.: Cambridge, MA, USA, 2016.

25. Gutiérrez-Aguirre, I.; Mehle, N.; Delić, D.; Gruden, K.; Mumford, R.; Ravnikar, M. Real-time quantitative PCR based sensitive detection and genotype discrimination of Pepino mosaic virus. J. Virol. Methods 2009, 162, 46-55. [CrossRef]

26. Torre, C.; Donaire, L.; Gómez-Aix, C.; Juárez, M.; Peterschmitt, M.; Urbino, C.; Hernando, Y.; Agüero, J.; Aranda, M.A. Characterization of begomoviruses sampled during severe epidemics in tomato cultivars carrying the Ty-1 Gene. Int. J. Mol. Sci. 2018, 19, 2614. [CrossRef] [PubMed]

27. Ciuffo, M.; Kinoti, W.M.; Tiberini, A.; Forgia, M.; Tomassoli, L.; Constable, F.E.; Turina, M. A new blunervirus infects tomato crops in Italy and Australia. Arch. Virol. 2020, 165, 2379-2384. [CrossRef] [PubMed]

28. Borodynko, N.; Hasiów-Jaroszewska, B.; Pospieszny, H. Identification and characterization of an Olive latent virus 1 isolate from a new host: Solanum lycopersicum. J. Plant Pathol. 2010, 92, 789-792.

29. Visser, M.; Bester, R.; Burger, J.T.; Maree, H.J. Next-generation sequencing for virus detection: Covering all the bases. Virol. J. 2016, 13, 1-6. [CrossRef] [PubMed]

30. García, Y.G.; Montoya, M.M.; Gutiérrez, P.A. Detection of RNA viruses in Cape gooseberry (Physalis peruviana L.) by RNAseq using total RNA and dsRNA inputs. Arch. Phytopathol. Plant Prot. 2020, 53, 395-413. [CrossRef]

31. Czosnek, H.; Ber, R.; Navot, N.; Antignus, Y.; Cohen, S.; Zamir, D. Tomato yellow leaf curl virus DNA forms in the viral capside, in infected plants and in the insect vector. J. Phytopathol. 1989, 125, 47-54. [CrossRef]

32. Maree, H.J.; Fox, A.; Al Rwahnih, M.; Boonham, N.; Candresse, T. Application of HTS for routine plant virus diagnostics: State of the art and challenges. Front. Plant Sci. 2018, 9, 1082. [CrossRef]

33. Al Rwahnih, M.; Daubert, S.; Golino, D.; Islas, C.; Rowhani, A. Comparison of next-generation sequencing versus biological indexing for the optimal detection of viral pathogens in grapevine. Phytopathology 2015, 105, 758-763. [CrossRef]

34. Candresse, T.; Filloux, D.; Muhire, B.; Julian, C.; Galzi, S. Appearances Can Be Deceptive: Revealing a Hidden Viral Infection with Deep Sequencing. PLoS ONE 2014, 9, e102945. [CrossRef] [PubMed]

35. Akinyemi, I.A.; Wang, F.; Zhou, B.; Qi, S.; Wu, Q. Ecogenomic survey of plant viruses infecting tobacco by next generation sequencing. Virol. J. 2016, 13, 181. [CrossRef]

36. Alcalá-Briseño, R.I.; Casarrubias-Castillo, K.; López-Ley, D.; Garrett, K.A.; Silva-Rosales, L. Network analysis of the papaya oroecological regions of Chiapas, Mexicochard virome from two agr. Msystems 2020, 5, e0042319. [CrossRef] [PubMed]

37. Bernal-Vicente, A.; Donaire, L.; Torre, C.; Gómez-Aix, C.; Sánchez-Pina, M.A.; Juarez, M.; Hernando, Y.; Aranda, M.A. Small RNA-seq to characterize viruses responsible of Lettuce big vein disease in Spain. Front. Microbiol. 2018, 9, 3188. [CrossRef] [PubMed]

38. Jo, Y.; Bae, J.-Y.; Kim, S.-M.; Choi, H.; Lee, B.C.; Cho, W.K. Barley RNA viromes in six different geographical regions in Korea. Sci. Rep. 2018, 8, 1-13. [CrossRef] [PubMed]

39. Mumo, N.N.; Mamati, G.E.; Ateka, E.M.; Rimberia, F.K.; Asudi, G.O.; Boykin, L.M.; Machuka, E.M.; Njuguna, J.N.; Pelle, R.; Stomeo, F. Metagenomic Analysis of Plant Viruses Associated With Papaya Ringspot Disease in Carica papaya L. in Kenya. Front. Microbiol. 2020, 11, 205. [CrossRef]

40. Skums, P.; Artyomenko, A.; Glebova, O.; Ramachandran, S.; Campo, D.S.; Dimitrova, Z.; Măndoiu, I.I.; Zelikovsky, A.; Khudyakov, Y. Pooling Strategy for Massive Viral Sequencing. In Computational Methods for Next Generation Sequencing Data Analysis; Măndoiu, I., Zelikovsky., A., Eds.; John Wiley \& Sons, Inc.: Hoboken, NJ, USA, 2016; pp. 57-83.

41. Agüero, J.; Gómez-Aix, C.; Sempere, R.N.; García-Villalba, J.; García-Núñez, J.; Hernando, Y.; Aranda, M.A. Stable and broad spectrum cross-protection against Pepino mosaic virus attained by mixed infection. Front. Plant Sci. 2018, 9, 1810. [CrossRef]

42. Gómez, P.; Sempere, R.N.; Elena, S.F.; Aranda, M.A. Mixed infections of Pepino mosaic virus strains modulate the evolutionary dynamics of this emergent virus. J. Virol. 2009, 83, 12378-12387. [CrossRef]

43. Fiallo-Olivé, E.; Navas-Castillo, J. Tomato chlorosis virus, an emergent plant virus still expanding its geographical and host ranges. Mol. Plant Pathol. 2019, 20, 1307-1320. [CrossRef]

44. Navas-Castillo, J.; López-Moya, J.J.; Aranda, M.A. Whitefly-Transmitted RNA Viruses that Affect Intensive Vegetable Production. Ann. Appl. Biol. 2014, 165, 155-171. [CrossRef]

45. Orílio, A.F.; Fortes, I.M.; Navas-Castillo, J. Infectious cDNA clones of the crinivirus Tomato chlorosis virus are competent for systemic plant infection and whitefly-transmission. Virology 2014, 464, 365-374. [CrossRef]

46. Navas-Castillo, J.; Fiallo-Olivé, E.; Sánchez-Campos, S. Emerging Virus Diseases Transmitted by Whiteflies. Annu. Rev. Phytopathol. 2011, 49, 219-248. [CrossRef]

47. Elvira-Gonzalez, L.; Carpino, C.; Alfaro Fernández, A.O.; Font San Ambrosio, M.I.; Peiró Barber, R.M.; Rubio MIgélez, L.; Galipienso-Torregrosa, L. A sensitive real-time RT-PCR reveals a high incidence of Southern tomato virus (STV) in Spanish tomato crops. Span. J. Agric. Res. 2018, 16. [CrossRef]

48. Campbell, R.N.; Lot, H. Lettuce ring necrosis, a viruslike disease of lettuce: Evidence for transmission by Olpidium brassicae. Plant Dis. 1996, 80, 611-615. [CrossRef]

49. Gallitelli, D.; Savino, V. Olive latent virus-1, an isometric virus with a single RNA species isolated from olive in Apulia, Southern Italy. Ann. Appl. Biol. 1985, 106, 295-303. [CrossRef]

50. Kanematsu, S.; Yumiko, T.; Morikawa, T. Isolation of Olive latent virus 1 from tulip in Toyama Prefecture. J. Gen. Plant Pathol. 2001, 67, 333-334. [CrossRef] 
51. Martelli, G.P.; Yilmaz, M.A.; Savino, V.; Baloglu, S.; Grieco, F.; Güldür, M.E.; Greco, N.; Lafortezza, R. Properties of a citrus isolate of olive latent virus 1, a new necrovirus. Eur. J. Plant Pathol. 1996, 102, 527-536. [CrossRef]

52. Quito-Avila, D.F.; Freitas-Astúa, J.; Melzer, M.J. Bluner-, Cile-, and higreviruses (kitaviridae). Encycl. Virol. $2020,3,247-251$.

53. Moreno, A.B.; López-Moya, J.J. When viruses play team sports: Mixed infections in plants. Phytopathology 2020, 110, 29-48. [CrossRef]

54. Massart, S.; Candresse, T.; Gil, J.; Lacomme, C.; Predajna, L.; Ravnikar, M.; Reynard, J.-S.; Rumbou, A.; Saldarelli, P.; Škorić, D. A framework for the evaluation of biosecurity, commercial, regulatory, and scientific impacts of plant viruses and viroids identified by NGS technologies. Front. Microbiol. 2017, 8, 45. [CrossRef] 